\title{
HUBUNGAN ANTARA PERSEPSI PEMUSTAKA TENTANG LAYANAN SIRKULASI MANDIRI DAN TINGKAT KEPUASAN PEMUSTAKA PADA PERPUSTAKAAN UNIVERSITAS PENDIDIKAN INDONESIA
}

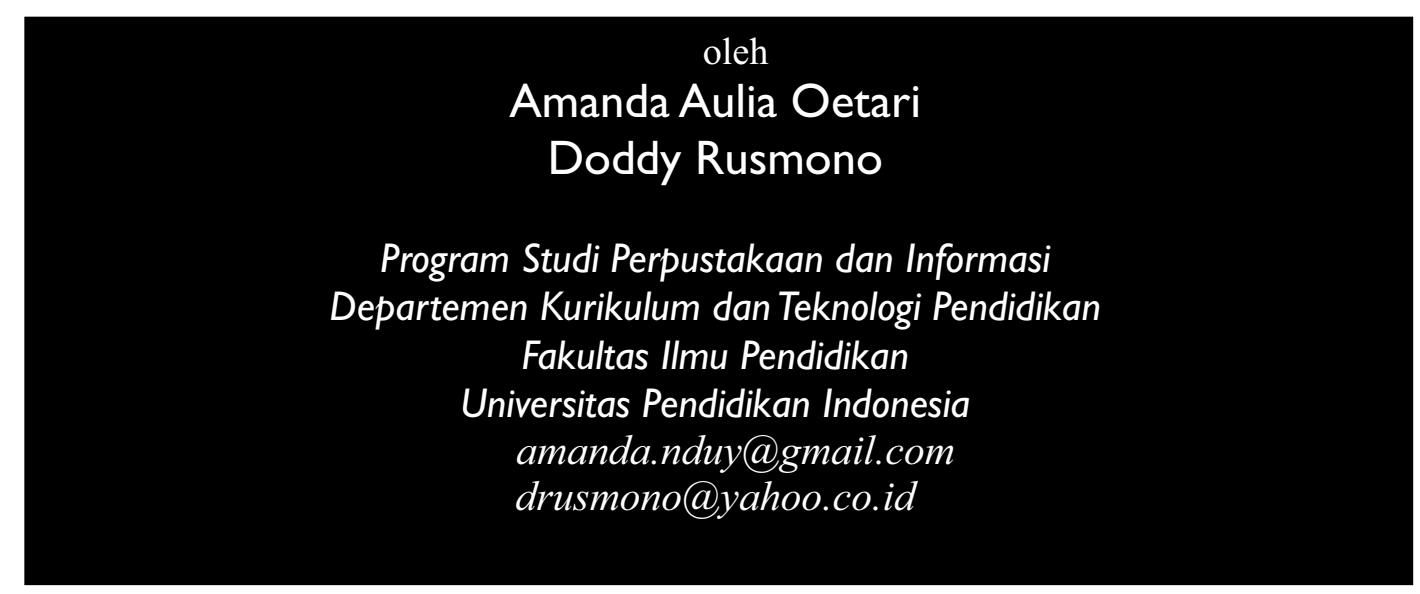

\begin{abstract}
ABSTRAK
Penelitian ini dilatarbelakangi dengan masuknya era informasi dan teknologi informasi dimana perpustakaan merupakan tempat untuk memperoleh informasi. Masalah yang menjadi kajian dalam penelitian ini difokuskan pada persepsi pemustaka tentang layanan sirkulasi mandiri dengan tingkat kepuasan pemustaka. Permasalahan pokok pada penelitian ini adalah bagaimana hubungan antara persepsi pemustaka tentang layanan sirkulasi mandiri dan tingkat kepuasan pemustaka. Tujuan penelitian ini adalah untuk mengetahui hubungan antara persepsi pemustaka tentang layanan sirkulasi mandiri dan tingkat kepuasan pemustaka. Metode penelitian ini menggunakan metode deskriptif dengan jenis studi korelasional. Populasi dalam penelitian ini adalah pemustaka perpustakaan UPI Bandung, dengan sampel 100 orang yang dihitung menggunakan rumus Yamane dengan metode simple random sampling. Instrumen yang digunakan adalah angket (kuesioner) tertutup dengan skala Likert dengan analisis data menggunakan studi deskriptif dan korelasi. Berdasarkan hasil analisis data persepsi pemustaka tentang layanan sirkulasi mandiri memiliki hasil yang cukup baik. Tingkat kepuasan pemustaka di Perpustakaan UPI Bandung yang tingkat kepuasannya cukup, lebih tinggi dari kategori lain. Hubungan persepsi pemustaka tentang layanan sirkulasi mandiri berpengaruh kuat terhadap tingkat kepuasan pemustaka. Rekomendasi untuk perpustakaan, pemustaka, dan peneliti selanjutnya, agar pemustaka lebih merasakan persepsi yang "sangat baik" dan "sangat puas" tentang layanan sirkulasi mandiri perpustakaan lebih dipertahankan dan ditingkatkan lagi mengenai informasi tentang layanan sirkulasi mandiri dan memperbanyak item dari layanan sirkulasi mandiri.
\end{abstract}

Kata Kunci: Persepsi, Pemustaka, Sirkulasi, Layanan, Mandiri, dan Kepuasan. 


\section{ABSTRACT}

The background of this research is the coming of information and information technology era, which make library is the important place to get information. The problem in this research is focused on librarian perception about self circulation service with Pemustaka satisfaction level. The basic problem in this research is how the correlation between Pemustaka perception about self circulation service and librarian satisfaction level. The research aim to know the correlation of Pemustaka perception about self circulation service and Pemustaka satisfaction level. The method of this research use descriptive method which use corelational study. Population in this research is the Pemustaka of library UPI, with the sample is 100 users library, which count use Yamane formula with simple random sampling method. The instrument in this research is close questioner with Likert scale, and the analyze data used descriptive study and correlation. The result of analyze data show that Pemustaka perception about self circulation service is adequate well. Pemustaka satisfaction level in library of UPI have adequate level of satisfaction, more high than another categories. The correlation Pemustaka perception about self circulation service have strong influential toward Pemustaka satisfaction level. The recommendation for library, Pemustaka, and the next researcher, is Pemustaka will fell "very well" and "very satisfaction" perception about the self circulation service of library, and library hopefully can keep the service level on self circulation service and increase the information of self circulation service, and the last hope library can added more item of self circulation service.

Keywords : Perception, Pemustaka, Circulation, Service, Self, and Satisfaction. 


\section{PENDAHULUAN}

Abad 21 ini merupakan era informasi dimana informasi bisa diperoleh di perpustakaan ataupun di sentra-sentra informasi. Perpustakaan juga ikut andil dalam perkembangan informasi karena perpustakaan merupakan salah satu tempat untuk memberikan pelayanan untuk memperoleh segala macam informasi. Kebutuhan akan teknologi informasi sangat terhubung dengan peran perpustakaan sebagai penyebar informasi yang bersifat umum atau ilmu pengetahuan, tempat sebagai rujukan bagi para pencari ilmu, dan pengembangan karya-karya ilmiah. Teknologi informasi di Perpustakaan Universitas Pendidikan Indonesia (UPI) yang sering digunakan secara perorangan oleh para pemustaka berada pada layanan sirkulasi mandiri. Layanan sirkulasi mandiri adalah salah satu layanan mandiri dimana para pemustaka dapat mencari sendiri letak keberadaan bahan-bahan pustaka, meminjam dan mengembalikan buku secara mandiri. Layanan sirkulasi mandiri ini memiliki peran sangat penting bagi perpustakaan UPI selain sebagai alat yang dapat memberikan kontribusi yang sangat besar dalam menunjang kegiatan perpustakaan, dapat juga sebagai pengembangan ilmu pengetahuan. Jika semakin berkembang ilmu pengetahuan maka semakin berkembang pula proses digitalisasi perpustakaan yang bisa membawa perubahan dalam memberikan layanan perpustakaan. MPS dan Book Drop merupakan suatu produk dari Electronic Library Management System (ELIMS) yang digunakan di Perpustakaan UPI pada saat ini. MPS dan Bookdrop adalah suatu pusat layanan sirkulasi mandiri dalam kegiatan peminjaman dan pengembalian koleksi yang dapat dilakukan secara mandiri oleh pemustaka. Pelayanan sirkulasi mandiri ini dapat membawa kepuasan bagi pemustaka.

Berdasarkan pengamatan yang penulis lakukan sebelum melaksanakan penelitian, penulis mendapatkan fakta mengenai pemustaka perpustakaan UPI. Terdapat perbedaan yang sangat jauh dengan adanya prosentase antara pengunjung dan peminjam bahan pustaka. Hal ini mengindikasikan bahwa terdapat dua kemungkinan apakah layanan sirkulasi mandiri berupa MPS dan Bookdrop memberikan dampak terhadap kurangnya keinginan pemustaka dalam meminjam bahan pustaka yang ada di Perpustakaan UPI ini, ataukah karena kurangnya kepuasan pemustaka terhadap informasi dalam penggunaan MPS dan Bookdrop.

Identifikasi permasalahan dari penelitian ini antara lain terjadinya peningkatan kebutuhan informasi yang belum dipenuhi oleh perpustakaan, hadirnya teknologi informasi di perpustakaan yang belum banyak diketahui oleh pemustaka, adanya penerapan layanan sirkulasi mandiri yang belum difahmi oleh sebagian besar pemustaka, dan kurangnya pengetahuan pemustaka tentang layanan sirkulasi mandiri. Rumusan masalah dalam penelitian ini dibagi menjadi dua yaitu rumusan masalah umum dan rumusan masalah khusus. Rumusan masalah umum yaitu bagaimanakah hubungan antara persepsi pemustaka tentang layanan sirkulasi mandiri dan tingkat kepuasan pemustaka di Perpustakaan UPI. Rumusan masalah khusus yaitu bagaimanakah persepsi pemustaka tentang layanan sirkulasi mandiri di Perpustakaan UPI, seberapa tingginyakah tingkat kepuasan pemustaka terkait dengan layanan sirkulasi mandiri di Perpustakaan UPI, bagaimanakah hubungan persepsi pemustaka tentang MPS dengan tingkat kepuasan pemustaka di Perpustakaan UPI, dan bagaimanakah hubungan persepsi pemustaka tentang Bookdrop dengan tingkat kepuasan pemustaka di Perpustakaan UPI.

Dalam penelitian ini terdapat tujuan penelitian umum dan tujuan penelitian khusus. Tujuan penelitian umum yaitu untuk mengetahui hubungan antara persepsi pemustaka tentang layanan sirkulasi mandiri dan tingkat kepuasan pemustaka di Perpustakaan UPI. Tujuan penelitian khusus yaitu untuk mengetahui persepsi pemustaka tentang layanan sirkulasi mandiri di Perpustakaan UPI, untuk mengetahui seberapa tingginyakah tingkat kepuasan pemustaka terkait dengan layanan sirkulasi mandiri di Perpustakaan UPI, untuk mengetahui hubungan persepsi pemustaka tentang MPS dengan tingkat kepuasan pemustaka di Perpustakaan UPI, dan untuk 
mengetahui hubungan persepsi pemustaka tentang Bookdrop dengan tingkat kepuasan pemustaka di Perpustakaan UPI. Manfaat penelitian dari penelitian ini terbagi dua yaitu manfaat penelitian dari segi teoritis dan dari segi praktis. Secara teoritis Penelitian ini diharapkan dapat memberikan kontribusi besar kepada para pemustaka atas kemudahan-kemudahan dalam menggunakan layanan sirkulasi mandiri khususnya di Perpustakaan UPI. Secara praktis penelitian ini bagi pustakawan, penelitian ini diharapkan dapat memberikan pencerahan positif terhadap kesulitan dan kekurangan pemustaka dalam menggunakan layanan sirkulasi mandiri, sedanghkan bagi pemustaka, penelitian ini dapat membuat pemustaka merasa nyaman dan mudah dalam menggunakan layanan sirkulasi mandiri yang berada di perpustakaan.

\section{PEMBAHASAN}

Persepsi pemustaka merupakan suatu pengamatan yaitu melalui suatu proses stimulus yang datang kepada manusia dan memberikan makna pada stimulus tersebut. Jadi pengamatan merupakan penginderaan yang disertai pemaknaan serta sifatnya psikologis, berarti selain diinderakan juga disadari atau dipahami oleh pemustaka. Persepsi yang dimaksud dalam penelitian ini mengacu pada apa yang distimuluskan. Sarlito dalam Martini, Nina dan Ida (2010:4.3) dinyatakan bahwa persepsi merupakan “kemampuan untuk mengorganisasikan pengamatan." Jadi dapat disimpulkan bahwa persepsi merupakan proses pemberian makna kepada informasi sensoris yang diterima seseorang." Persepsi seseorang tidak timbul begitu saja, melainkan dipengaruhi oleh berbagai faktor, baik internal (faktor intern) ataupun eksternal (faktor ekstern). Faktor internal berasal dari dalam diri individu, misalnya sikap, kebiasaan, dan kemauan. Sedangkan faktor eksternal adalah faktor-faktor yang berasal dari luar individu yang meliputi stimulus itu sendiri, baik sosial maupun fisik. Persepsi pada umumnya terjadi karena dua faktor, yaitu faktor internal dan faktor eksternal sebagai berikut.

1. Faktor internal

Faktor-faktor yang mempengaruhi persepsi yang terdapat dalam diri individu, yang mencakup beberapa hal antara lain: kebutuhan, minat, set.

\section{Faktor eksternal}

Faktor eksternal yang mempengaruhi persepsi, yang dilalui oleh stimulus, yaitu: intensitas/ukuran, kontras/ sesuatu yang baru (novelty), repetisi/frekuensi, gerakan. (Martini, Nina dan Ida 2010:4.54.6)

Berdasarkan pendapat di atas dapat disimpulkan bahwa faktor-faktor dalam persepsi yang mempengaruhi persepsi tidak hanya dipengaruhi oleh faktor stimulus yang datang dari lingkungannya, tetapi dipengaruhi oleh faktor dari dalam individu dengan berbagai karakteristiknya. Terjadinya persepsi sendiri harus didukung oleh alat indera yang cukup baik sebagai organ penerima dengan karakteristik dan perhatian dari individu terhadap stimulus.

Merujuk Kamus Besar Bahasa Indonesia (1991:949) Pengertian "sirkulasi adalah peredaran". Di dunia perpustakaan sirkulasi lebih sering dikenal sebagai titik layanan peminjaman. Namun, pengertian layanan sirkulasi sebenarnya mencakup seluruh kegiatan pencatatan yang berkaitan dengan pemanfaatan koleksi. Dengan pengertian tersebut dapat dipahami bahwa "layanan sirkulasi yakni semua bentuk kegiatan yang berkaitan dengan pemanfaatan, pemakaian koleksi dengan tepat guna dan tepat waktu untuk kepentingan pemakai jasa perpustakaan" (Lasa HS, 2008:312).

Automasi pada perpustakaan dalam peminjaman dan pengembalian bahan pustaka merupakan automasi berbasis RFID (Radio Frequency Identification Device) dimana pengertiannya adalah "sebuah metode identifikasi dengan menggunakan sarana yang disebut label RFID atau transponder untuk menyimpan dan mengambil data jarak 
jauh" (http://id.wikipedia.org). Layanan pemustaka didefinisikan sebagai aktivitas perpustakaan dalam memberikan jasa layanan kepada pemustaka perpustakaan khususnya kepada anggota perpustakaannya. Sedangkan mandiri menurut kamus besar bahasa Indonesia (1991:625) adalah "keadaan yang dapat berdiri sendiri atau tidak bergantung pada orang lain". Dapat disimpulkan bahwa Layanan sirkulasi mandiri merupakan layanan peminjaman dan pengembalian yang dapat dilakukan secara individu atau tidak bergantung pada pustakawan atau orang lain.

Dalam layanan sirkulasi mandiri ini pemustaka melakukan sendiri dalam suatu proses peminjaman dan pengembalian bahan pustaka. Alat yang dapat melakukan kegiatan peminjaman dan pengembalian bahan pustaka tersebut disebut Multi Purpose Station (MPS) sedangkan bookdrop adalah alat yang melakukan kegiatan pengembalian bahan pustaka yang dapat digunakan oleh pemustaka pada waktu jam layanan perpustakaan buka ataupun jam layanan perpustakaan tutup. Kedua alat tersebut merupakan salah satu produk dari Electronic Library Management System (ELiMS) dengan menggunakan teknologi RFID (Radio Frequency Identification Device).

Dimensi kualitas layanan menurut Parasuraman dalam Rochaety (2006:108) meliputi :

(1) Ketersediaan fasilitas

Yaitu meliputi fasilitas fisik, penampilan menu, perlengkapan, dan sarana yang diperoleh dari penggunaan MPS dan bookdrop seperti jumlah ketersediaan alat, tempat yang nyaman dan menumenu yang ditawarkan pada MPS dan bookdrop tersebut.

(2) Kehandalan

Yaitu kemampuan memberikan pelayanan yang menjanjikan dengan cepat, akurat dan memuaskan. Misalnya layanan yang sesuai dengan kebutuhan, efisiensi waktu, proses yang akurat, serta aktivitas yang dapat memperlancar proses kegiatan. Dalam hal ini adalah kegiatan peminjaman dan pengembalian bahan pustaka dengan fasilitas MPS dan bookdrop.

(3) Daya tanggap

Yaitu kemampuan untuk merespon. Misalnya kecepatan alat dalam merespon perintah-perintah yang diberikan oleh pemustaka melalui menu-menu yang tersedia pada layanan MPS dan bookdrop.

(4) Jaminan

Yaitu kemampuan MPS dan bookdrop dalam hal keamanan data-data peminjaman dan pengembalian koleksi, sehingga pemustaka merasa nyaman dalam memanfaatkan layanan perpustakaan.

(5) Kemudahan

Yaitu tingkat kesulitan yang rendah dalam menggunakan fasilitas perpustakaan dengan membuat penampilan data yang mudah dipahami dan jelas. Misalnya kemudahan dalam mengoperasikan menu-menu pada MPS dan bookdrop seperti peminjaman dan pengembalian bahan pustaka.

Kepuasan atau satisfaction adalah kata dari bahasa latin, yaitu statis yang berarti enough atau cukup dan facer yang berarti to do atau melakukan. "Jadi, produk atau jasa yang bisa memuaskan adalah produk dan jasa yang sanggup memberikan sesuatu yang dicari oleh konsumen sampai pada tingkat cukup" (Irawan, 2002:2). Menurut Kotler dalam Tjiptono (1996:146) menyatakan kepuasan adalah "tingkat perasaan seseorang setelah membandingkan kinerja/hasil yang dirasakannya dengan harapannya". Dapat diambil kesimpulan bahwa tingkat kepuasan merupakan perbedaan antara kinerja yang dirasakan dengan harapan. Jadi jika kenyataan jauh dari sebuah harapan yang dirasakan, maka seseorang akan merasa kecewa. Dalam upaya mencapai kepuasan pemustaka, ada hal yang perlu diperhatikan, bahwa tidak ada strategi yang ajaib dalam

Amanda Aulia Oetari,Hubungan Antara Persepsi Pemustaka Tentang Layanan Sirkulasi Mandiri dan Tingkat Kepuasan Pemustakadi Perpustakaan Pendidikan Indonesia 
kepuasan pelanggan. Kepuasan pelanggan tercipta mulai dari hal-hal yang detil atau rinci, hal-hal yang rutin dan dimulai jauh hari sebelum produk dan jasa diproduksi. "Karena kepuasan pelanggan harus dimulai dari hati, yaitu kesadaran dan kecintaan terhadap pelanggan"(Irawan, 2002:4).

Pengukuran kepuasan pemakai dimaksudkan untuk menilai tingkat kepuasan terhadap jasa perpustakaan secara keseluruhan atau per jenis jasa. Hernon (1998:159) mengungkapkan untuk mengukur kepuasan pemakai dapat dilihat dari 2 faktor, yaitu:

1). Staf, variabel yang dapat dilihat antara lain yaitu wawasan pengetahuan petugas dapat menjaga kepercayaan, keinginan dalam menolong, keramahan, sabar, menarik, semangat.

2). Informasi yang diberikan, variabel yang dapat dilihat yaitu, keakuratan, jumlah informasi, kelengkapan dan manfaat informasi yang diberikan.

Dalam penilitian ini penulis dalam mengukur kepuasan pemustaka dengan memfokuskan hanya pada faktor memperoleh sumber-sumber informasi saja. Karena penilitian yang penulis ajukan adalah tentang kepuasan pemustaka dengan adanya layanan sirkulasi mandiri. Kepuasan pemustaka dalam penelitian ini adalah suatu penilaian pemustaka dalam menggunakan layanan di Perpustakaan UPI Bandung khususnya dalam layanan sirkulasi mandiri. Layanan sirkulasi mandiri merupakan layanan yang diberikan kepada pemustaka dalam hal peminjaman dan pengembalian bahan pustaka yang menggunakan sistem automasi. Para pemustaka dalam melakukan peminjaman dan pengembalian bahan perpustakaan dapat secara mandiri tanpa melalui bantuan pustakawan. Kepuasan pemustaka ini dapat dilihat melalui daftar kunjungan pemustaka dalam peminjaman dan pengembalian bahan pustaka. Sedangkan persepsi pemustaka tentang layanan sirkulasi mandiri dinilai dari alat layanan sirkulasi mandiri yang terdiri dari
MPS dan bookdrop di Perpustakaan UPI Bandung.

Akan terlihat keterkaitan antara persepsi pemustaka tentang layanan sirkulasi mandiri dan tingkat kepuasan pemustaka, dari persepsi yang diberikan oleh pemustaka tentang layanan sirkulasi mandiri dan tingkat kepuasan pemustaka di Perpustakaan UPI. Jika persepsi yang dihasilkan positif maka pemustaka merasa puas akan adanya layanan sirkulasi mandiri, sedangkan jika persepsi yang dihasilkan negatif maka terlihat bahwa pemustaka tidak puas akan layanan sirkulasi mandiri.

Populasi dalam penelitian ini adalah pemustaka yang meminjam bahan pustaka di perpustakaan UPI berdasarkan statistik pengunjung bulan Desember 2012. Adapun jumlah pengunjung perpustakaan UPI dari bulan Desember 2012 adalah sebanyak 5213 orang. sampel penelitian dalam penelitian ini adalah anggota populasi yang diambil menggunakan teknik sampling simple random sampling. Banyaknya sampel dalam penelitian ini adalah 100 orang pemustaka. Penelitian ini menggunakan pendekatan kuantitatif dengan metode penelitian deskriptif.

Analisis data yang digunakan dalam penelitian ini adalah analisis statistic deskriptif, analisis statistic parametris, dan uji hipotesis melalui rumus Koefisien Korelasi oleh Pearson Product Moment. Hasil uji korelasi pada tabel dibawah ini menunjukkan nilai korelasi antara persepsi pemustaka tentang layanan sirkulasi mandiri dan tingkat kepuasan pemustaka di Perpustakaan UPI.

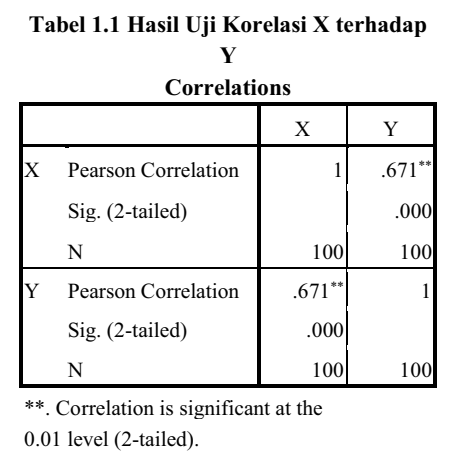


Berdasarkan tabel di atas dapat diketahui bahwa korelasi antara persepsi pemustaka tentang layanan sirkulasi mandiri dengan tingkat kepuasan pemustaka di Perpustakaan UPI sebesar 0,671. Jika nilai $r$ tersebut diinterpretasikan dengan menggunakan kriteria koefisien korelasi maka nilai $r$ berada pada interval koefisien korelasi 0,60 - 0,799. Dengan demikian besarnya korelasi $r=0,671$ dapat dikategorikan kuat.

Selanjutnya untuk mengetahui apakah nilai $\mathrm{r}$ tersebut memiliki arti atau tidak, dilakukan uji hipotesis korelasi Pearson dengan rumus yakni sebagai berikut.

$$
\begin{aligned}
t=\frac{r \sqrt{n-2}}{\sqrt{1-r^{2}}}= & \frac{0,671 \sqrt{100-2}}{\sqrt{(1-0,450)}}=\frac{6,643}{0,450} \\
& =14,761
\end{aligned}
$$

Dari perhitungan nilai $\mathrm{r}$ dan $\mathrm{t}$ di atas, peneliti menyimpulkan sebagai berikut:

\begin{tabular}{|c|c|c|c|c|}
\hline $\mathbf{R}$ & Kriteria & $\mathbf{T}_{\text {hitung }}$ & $\mathbf{t}_{\text {tabel }}$ & Keterangan \\
\hline 0,671 & Kuat & 14,761 & 1,984 & Signifikan \\
\hline
\end{tabular}

Dari hasil perhitungan diperoleh nilai $\mathrm{t}_{\text {hitung }}$ $=14,761$ dan $t_{\text {tabel }}=1,984$, maka $t_{\text {hitung }}>t_{\text {tabel }}$ artinya hipotesisi umum diterima dengan signifikansi 14,761 > 1,984 berupa kriteria signifikan. Dapat disimpulkan bahwa terdapat hubungan yang signifikan antara persepsi pemustaka tentang layanan sirkulasi mandiri dengan tingkat kepuasan pemustaka di Perpustakaan UPI. Hubungan ini ditunjukkan dengan nilai korelasi sebesar 0,671 yang termasuk kedalam kriteria kuat.

Peneliti juga melakukan uji korelasi pada setiap subvariabel variabel $\mathrm{X}$ terhadap $\mathrm{Y}$. tujuan dilakukannya uji korelasi pada setiap subvariabelnya untuk mendapatkan hasil data yang akurat dan mengetahui subvariabel mana yang memiliki hubungan paling besar dengan variabel $Y$. adapun hasil perhitungan korelasi dari setiap subvariabel sebagai berikut
Table 1.3 Hasil Uji Hipotesis $\mathrm{X}_{1}$ terhadap $Y$ Correlations.

\begin{tabular}{|c|c|c|c|}
\hline & & $\mathrm{X} 1$ & $\mathrm{Y}$ \\
\hline \multirow[t]{3}{*}{$\mathrm{X} 1$} & Pearson Correlation & 1 & $.594^{* *}$ \\
\hline & Sig. (2-tailed) & & .000 \\
\hline & $\mathrm{N}$ & 100 & 100 \\
\hline \multirow[t]{3}{*}{ Y } & Pearson Correlation & $.594^{* *}$ & 1 \\
\hline & Sig. (2-tailed) & .000 & \\
\hline & $\mathrm{N}$ & 100 & 100 \\
\hline
\end{tabular}

Berdasarkan tabel di atas, dapat diketahui bahwa korelasi antara MPS dengan kepuasan pemustaka sebesar 0,594. Jika nilai $r$ tesebut diinterpretasikan dengan menggunakan kriteria pada tabel maka nilai $r$ berada pada interval koefisien korelasi 0,40 - 0,599, dengan demikian besarnya $r=0,594$ dapat dikategorikan sedang.

Tabel 1.4 Hasil Uji Hipotesis $\mathrm{X}_{2}$ terhadap $\mathrm{Y}$ Correlations

\begin{tabular}{|ll|r|r|}
\hline & \multicolumn{1}{|c|}{ X1 } & \multicolumn{1}{|c|}{ Y } \\
\hline X1 & Pearson Correlation & 1 & $.616^{* *}$ \\
& Sig. (2-tailed) & & .000 \\
N & 100 & 100 \\
\hline Y Pearson Correlation & $.616^{* *}$ & 1 \\
& Sig. (2-tailed) & .000 & \\
N & 100 & 100 \\
\hline
\end{tabular}

**. Correlation is significant at the

0.01 level (2-tailed).

Berdasarkan tabel di atas, dapat diketahui bahwa korelasi antara Bookdrop dengan kepuasan pemustaka sebesar 0,616. Jika nilai $r$ tesebut diinterpretasikan dengan menggunakan kriteria pada tabel maka nilai $r$ berada pada interval koefisien korelasi 0,60 0,799 , dengan demikian besarnya $r=0,616$ dapat dikategorikan kuat. 


\section{SIMPULAN}

Berdasarkan hasil penelitian yang dilakukan peneliti, kenyataan di lapangan menunjukkan terdapat hubungan yang signifikan antara persepsi pemustaka tentang layanan sirkulasi mandiri dan tingkat kepuasan pemustaka di Perpustakaan UPI. Hal ini menunjukkan Persepsi pemustaka tentang layanan sirkulasi mandiri memiliki hubungan yang kuat dengan tingkat kepuasan di Perpustakaan UPI.

Persepsi pemustaka tentang layanan sirkulasi mandiri cukup baik, dikarenakan layanan sirkulasi mandiri membantu para pemustaka dalam proses sirkulasi, namun masih ada sebagian besar pemustaka yang menyatakan kurang baik karena layanan sirkulasi mandiri masih jarang dikenal. Multi Purpose Station (MPS) merupakan fasilitas peminjaman mandiri yang berada di Perpustakaan UPI, sebagian besar pemustaka memiliki persepsi yang cukup baik tentang fasilitas tersebut tetapi sebagian pemustaka menyatakan kurang baik persepsinya terhadap MPS. Sedangkan fasilitas pengembalian mandiri yang biasa dikenal dengan Bookdrop sama halnya dengan MPS masih banyak pemustaka menyatakan cukup baik melalui persepsinya, namun sebagian lagi menyatakan kurang baik.

Tingkat kepuasan pemustaka terkait dengan layanan sirkulasi mandiri di Perpustakaan UPI memiliki kriteria cukup puas dan kriteria puas, dikarenakan layanan sirkulasi mandiri ini memudahkan para pemustaka dalam proses sirkulasi serta menghemat waktu dalam proses peminjaman dan pengembalian bahan pustaka/koleksi. Keakuratan informasi tentang layanan sirkulasi mandiri sudah cukup memuaskan oleh sebagian pemustaka dikarenakan mereka baru mengetahui layanan sirkulasi mandiri bahwa MPS digunakan untuk peminjaman bahan pustaka/koleksi dan Bookdrop hanya digunakan untuk pengembalian bahan pustaka/koleksi.

Jumlah informasi tentang layanan sirkulasi mandiri di Perpustakaan UPI sudah dirasakan cukup memuaskan oleh pemustaka dikarenakan dalam penggunaan layanan sirkulasi mandiri rata-rata pemustaka mengetahui layanan sirkulasi mandiri ketika mereka akan meminjam bahan pustaka/koleksi di perpustakaan, serta kurang banyaknya bahan pustaka yang dipinjam sebab perpustakaan hanya membatasi maksimal 5 buku untuk dipinjamkan. Dan dalam menggunakan layanan sirkulasi mandiri pemustaka membutuhkan waktu hanya 1 menit dalam prosesnya dan hal ini mengurangi antrian yang panjang dalam proses sirkulasi. Kelengkapan dan manfaat informasi tentang layanan sirkulasi mandiri di Perpustakaan UPI masih cukup memadai seperti yang dirasakan oleh pemustaka. Hal ini dikarenakan masih kurangnya informasi yang diterima oleh pemustaka.

Hubungan persepsi pemustaka tentang MPS dengan tingkat kepuasan pemustaka di Perpustakaan UPI sangat signifikan dikarenakan hubungan persepsi pemustaka tentang MPS dengan tingkat kepuasan pemustaka di Perpustakaan sangat sedang. Sedangkan hubungan persepsi pemustaka tentang bookdrop dengan tingkat kepuasan pemustaka di Perpustakaan UPI sangat signifikan dikarenakan hubungan persepsi pemustaka tentang bookdrop dengan tingkat kepuasan pemustaka di Perpustakaan sangat kuat.

\section{DAFTAR PUSTAKA}

Ajie, M. D. (2013). Otomasi

Perpustakaan:sebuah pengantar

[PDF]. Universitas Pendidikan Indonesia, Bandung, Indonesia.

Arikunto, S. (2006). Prosedur Penelitian suatu pendekatan praktik. Jakarta: Rineka Cipta. . (2010). Manajemen Penelitian. Jakarta: Rineka Cipta.

Bungsin, B.(2005). Metodologi Penelitian Kuantitatif. Jakarta: Kencana. 
Departemen Pendidikan dan

Kebudayaan. (1991). Kamus

Besar Bahasa Indonesia. Jakarta:

Balai Pustaka.

Hermawan, R \& Zulfikar, Z. (2010).

Etika Kepustakawanan:suatu

pendekatan terhadap kode etik

pustakawan Indonesia. Jakarta:

SagungSeto.

Hernon, Peter dan Altman Ellen. 1995.

Service Quality in Academic

Library. New Jersey:Ablex

Publishing corporation.

Irawan, H. (2002). Prinsip Kepuasan

Pelanggan. Jakarta: Elex Media

Komputer.

Kotler, P. (2003). Marketing

Management. New Jersey: Prentice Hall.

Lasa, HS. (2008). Manajemen

Perpustakaan. Yogyakarta: Gama

Media.

Martini, N. A dan Ida, F. (2010).

Psikologi Perpustakaan.

Jakarta: Universitas Terbuka.

Nurhadi, I. (2007). Pengguna

Perpustakaan dalam Warta

vol.XII no.1, pp.30

Perpustakaan Nasional RI.( 2009).

Undang-Undang Republik Indonesia

nomor 43

tahun 2007 tentang

perpustakaan. Jakarta:

Perpustakaan Nasional RI.

Rahayu, M. S. (2009). Psikologi Umum 1 jilid 2 [Diktat Kuliah]. Universitas Islam Bandung, Bandung, Indonesia.

Rahayuningsih. (2007). Pengelolaan

Perpustakaan. Yogyakarta:

Graha Ilmu.

Rakhmat, J. (1996). Psikologi

Komunikasi. Bandung: Remaja

Rosdakarya.

Rochaety, dkk. (2006). Sistem Informasi Manajemen Pendidikan.

Jakarta: Bumi Aksara.

Septiyanto, T \& Umar, S. (2003). Dasardasar Ilmu Perpustakaan dan
Informasi. Yogyakarta: Jurusan

Ilmu Perpustakaan dan

Informasi Fakultas Adab dan

Humaniora IAIN Sunan

Kalijaga.

Subrata, G. (2009). Automasi

Perpustakaan. Malang:

Universitas Negeri Malang.

Sudjana N dan Ibrahim. (2007).

Penelitian dan penilaian

Pendidikan. Bandung: Sinar

Baru Algensindo

Sugiyono. (2011). Metode penelitian

kuantitatif, kualitatif, dan

$R \& D$. Bandung: Alfabeta.

Sukmadinata, N. S. (2008). Metode penelitian pendidika. Bandung:

Remaja Rosdakarya.

Sulistyo-Basuki. (1992). Teknik dan Jasa

Dokumentasi. Jakarta:

Gramedia Pustaka Utama. (1993). Pengantar Ilmu

Perpustakaan. Jakarta:

Gramedia Pustaka Utama. (1994). Periodisasi

Perpustakaan Indonesia.

Bandung: Remaja Rosdakarya.

Suparman, (2007). Kajian Kepuasan

Pengguna Terhadap Kualitas

Layanan Perpustakaan Institut

Pertanian Bogor (Tesis).

Bogor: Institut Pertanian

Bogor.

Supriyanto, W \& Ahmad, M. (2008).

Teknologi Informasi

Perpustakaan. Yogyakarta:

Kanisius.

Suryana, L. I.( 2011). Psikologi Umum II (sensasi dan persepsi).

Bandung: Universitas Islam

Bandung Fakultas Psikologi.

Thoha, C. (2001). Teknik Evaluasi

Pendidikan. Jakarta: Raja

Grafindo

Tjiptono, F. (1996). Manajemen Jasa.

Yogyakarta: Andi.

Walgito, B. (2010). Pengantar Psikologi

Umum. Yogyakarta: Penerbit Andi..

Amanda Aulia Oetari,Hubungan Antara Persepsi Pemustaka Tentang Layanan Sirkulasi Mandiri dan Tingkat Kepuasan Pemustakadi Perpustakaan Pendidikan Indonesia 
Yusup, P. M.( 2001). Pengantar Aplikasi Teori Ilmu Sosial Komunikasi Untuk Perpustakaan dan Informasi. Bandung: Program Studi Ilmu Perpustakaan Fakultas Ilmu Komunikasi Universitas Padjajaran. . (2009). Ilmu Informasi,

Komunikasi, dan Kepustakaan. Jakarta: Bumi Aksara. . (2007). Electronic Library Management System (ELIMS). Diakses pada tanggal 8 april 2013 pada pukul 21.44, dari http://www.stlogitrack.com/pdf/ELiMS\%20 System $\% 20$ Overview.pdf 